\title{
Description of Anxiety Levels of Pre School Children With Thalassemia Who Will Get Blood Transfusion in the Thalassemia Poly at Al-Ihsan Baleendah Hospital, Bandung
}

\author{
Lisbet Octovia Manalu ${ }^{1, *}$ Budi Rustandi ${ }^{1}$ Budi Somantri ${ }^{1}$
}

\author{
${ }^{1}$ Rajawali Health Institute Bandung \\ *Corresponding author. Email: lisbetmanalu14@gmail.com
}

\begin{abstract}
The nursing process carried out by nurses in the hospital creates anxiety for patients, especially in children. The anxiety that is often shown by children when they are in hospital is when they get treatment in the hospital, especially when they are going to be doing invasive actions in children. The purpose of this study was to determine the description of anxiety levels in preschool children with thalassemia who will receive blood transfusions in Thalassemia Poly at Al-Ihsan Baleendah Hospital, Bandung. This study used a quantitative descriptive method with a sample of 30 respondents. The results of this study were analyzed using the frequency distribution formula. The results showed that 19 respondents had severe anxiety, 10 respondents had moderate anxiety and 1 respondent had mild anxiety. The conclusion in this study is that the largest presentation that appears is severe anxiety, namely $63.3 \%$. Suggestions that can be given are to further improve the FCC (Family Centered Care) as an optimal nursing care approach process.
\end{abstract}

Keywords: anxiety, thalassemia.

\section{INTRODUCTION}

The nursing process carried out by nurses in the hospital creates anxiety for patients, especially in children. The anxiety that is often shown by children when they are in hospital is when they get treatment in the hospital, especially when they are going to be doing invasive actions in children. Where is the condition of the child who will be given a blood transfusion, namely in thalassemia patients? When children have routine bad experiences in their lives, this will slow down the process of carrying out transfusions for thalassemia children, especially where the $\mathrm{Hb}$ child is already low. Thalassemia Poly in RSUD Al-Ihsan Baleendah Bandung operates in working hours, namely 08.0015.00 and the patient is already there and has been arranged to come regularly at $08.30-14.00$. This room consists of 8 beds that are used alternately with the allocation of transfusion time of around 2-3 hours and a rest period after transfusion of 15-20 minutes and after that the family and children leave the poly thalassemia room. Children always react at least once a month. The obstacles faced are that children tend to be less cooperative and respond negatively, even though the child is accompanied by their parents and has come for transfusions several times. In the poly thalassemia room there is already a television, but it appears that the pictures or programs that are watched by children are not according to their age, but so that the room has entertainment, the television is turned on to create entertainment in the room. From medical record data obtained from Al-Ihsan Baleendah Hospital, Bandung every month there are 30 children who regularly receive blood transfusions. Transfusions that are given regularly every month to children will show the child's psychosocial reactions to bad experiences in their life. [1] In children, we must understand the concept of atraumatic care, which is a form of therapeutic care provided by health workers in a child health care setting, through the use of measures that can reduce physical distress and psychological distress experienced by both children and parents [2]. 


\section{RESEARCH METHODS}

The type of research used is descriptive quantitative with variables in the form of anxiety of preschool children with thalassemia who will receive blood transfusion. The population in this study were preschool children who were going to undergo transfusions at AlIhsan Baleendah Hospital, Bandung totaling 30 people in one month. Sampling was done by total sampling. The data collection tool used was a questionnaire. The data obtained were analyzed using the frequency distribution formula.

\section{RESEARCH RESULT}

The results of the study by giving questionnaires to the patient's parents were carried out for 10 days during working hours, from 22 July 2020 to 4 August 2020 at the Thalassemia clinic at Al-Ihsan Baleendah Hospital, Bandung.

Based on table 1, it can be seen that of the 30 respondents almost half of the respondents were male (60\%), namely 18 respondents. Table 2 explains that there were 19 respondents $(63.3 \%)$ of 30 respondents who experienced severe anxiety.

Table 1. Frequency Distribution of Anxiety Levels in Children with Thalassemia before being given Puppet Play Therapy based on Gender of Respondents at RSUD Al-Ihsan Baleendah, Bandung

\begin{tabular}{|l|l|l|}
\hline Gender & N & \% \\
\hline Male & 18 & 60,0 \\
\hline Female & 12 & 40,0 \\
\hline Total & 30 & 100,0 \\
\hline
\end{tabular}

Table 2. Frequency Distribution of Anxiety Levels in Children with Thalassemia Before being given Puppet Play Therapy at Al-Ihsan Baleendah Hospital

\begin{tabular}{|l|l|l|}
\hline $\begin{array}{l}\text { Anxiety } \\
\text { Level }\end{array}$ & $\mathrm{N}$ & $\%$ \\
\hline Don't worry & 0 & 0.0 \\
\hline Mild anxiety & 1 & 3,4 \\
\hline $\begin{array}{l}\text { Moderate } \\
\text { Anxiety }\end{array}$ & 10 & 33.3 \\
\hline
\end{tabular}

\section{DISCUSSION}

Based on the results of the study showed that most of the respondents experienced mild anxiety, almost entirely 1 respondent was 3.4\%), and 10 respondents $(33.3 \%)$ experienced moderate anxiety, and 19 respondents $(63.3 \%)$ had severe anxiety.

This is different from research [3], where the number of respondents based on the anxiety category before being given therapy, there were 12 respondents who experienced moderate anxiety and only 3 respondents had severe anxiety. Severe anxiety is characterized by a significant decrease in perception. tends to focus on the details and not think about anything else. all behaviors are aimed at reducing anxiety and a lot of direction is needed to focus on other areas [4]

This anxiety phase can be minimized by providing therapeutic games to children. The support and role of nurses can help children adapt to their environment. Therapeutic play as a diversional or diversional activity helps children divert attention to activities they like [5]

In the existing questionnaire, question no.4 (I saw my child was sad when I left him) with 16 respondents where the children were worried if their parents were far away from their children. Related to this, the concept of FCC (Family Centered Care) must be improved because it has great power in reducing anxiety in children [5]

There were 4 respondents who answered "never" to the question I saw that my child was nervous when he saw a stranger / another patient who was receiving treatment beside / in the same room with him, but there were 13 respondents who answered "always" to this question no.11. One of the ways to minimize stressors or causes of stress is to involve parents taking an active role in child care [2].

Anxiety is an emotional assessment and response to something dangerous. Anxiety is closely related to feelings of uncertainty and helplessness [6]

This is supported by the condition of the respondent supported by the results of the researcher's observation that the respondent when the transfusion process was going to cry, even screamed, went berserk and refused to ask to go home and was irritable, anxious. The results of the researchers' observations also showed that children with thalassemia who were transfused asked their parents to accompany them during the transfusion process. Some even asked to hug them, some cried when their parents had to complete administration so they had to leave their children in the room. This is in line with existing theories and previous research. Supported by research [7] that children who experience procedures that cause pain 


\section{CONCLUSION}

Based on the results of research that has been conducted on 30 respondents regarding the level of anxiety of preschool children with thalassemia who will receive blood transfusions at Thalassemia Clinic at Baleendah Hospital, Bandung, that almost the majority of respondents $(63.3 \%)$ experience severe anxiety, from the results of research with 30 respondents where 16 respondents answered the child "often" where with the sound of the question: I saw my child sad when I left him) here must be determined the concept of FCC (Family Centered Care) must be continuously improved so that there is an integrated nursing care process.

\section{REFERENCES}

[1] Fahrudin, Adi dan Mulyani. (2011). Reaksi psikososial terhadap penyakit di kalangan anak penderita thalassemia mayor di kota bandung. Jurnal Informasi 16(3).

[2] Supartini, Yupi. Buku Ajar Konsep Dasar Keperawatan Anak. Jakarta:EGC. 2004.
[3] Katinawati, Sri Haryani, Syamsul Arif. 2006. Pengaruh Terapi Bermain dalam Menurunkan Kecemasan Pada Anak Usia Prasekolah (3-5 Tahun) Yang Mengalami Hospitalisasi di Rumah Sakit Umum Daerah Tugurejo Semarang

[4] Stuart. Gill.W. (2016). Keperawatan Kesehatan Jiwa: Indonesia: Elsevier.

[5] Hockenberry MJ, Wilson D, Rodgers CC. Wong's Essentials of Pediatric Nursing-E-Book: Elsevier health Sciences; 2016.

[6] Saputro, Fazrin. (2017). Anak Sakit Wajib Bermain di Rumah Sakit: Penerapan Terapi Bermain Anak Sakit; Proses, Manfaat dan Pelaksanaannya. Ponorogo: FORIKES.

[7] Putri, Mardhiyah, Widianti. Gambaran Respon Anak Usia Prasekolah dalam Menjalani Proses Transfusi. December; 2015. Volume 3, Nomor 3: pp. 176-184 